\title{
Reclaiming to Brackish Wetlands in the Alberta Oil Sands: Comparison of Responses to Sodium Concentrations by Carex atherodes and Carex aquatilis
}

\author{
Lilyan C. Glaeser*, Melissa House and Dale H. Vitt
}

check for updates

Citation: Glaeser, L.C.; House, M.; Vitt, D.H. Reclaiming to Brackish Wetlands in the Alberta Oil Sands: Comparison of Responses to Sodium Concentrations by Carex atherodes and Carex aquatilis. Plants 2021, 10, 1511. https://doi.org/10.3390/

plants10081511

Academic Editors: Ewa Hanus-Fajerska and Iwona Kamińska

Received: 24 June 2021

Accepted: 20 July 2021

Published: 23 July 2021

Publisher's Note: MDPI stays neutral with regard to jurisdictional claims in published maps and institutional affiliations.

Copyright: (c) 2021 by the authors. Licensee MDPI, Basel, Switzerland. This article is an open access article distributed under the terms and conditions of the Creative Commons Attribution (CC BY) license (https:// creativecommons.org/licenses/by/ $4.0 /)$.
School of Biological Sciences, Plant Biology, Southern Illinois University, Carbondale, IL 62901, USA; mhouse@siu.edu (M.H.); dvitt@siu.edu (D.H.V.)

* Correspondence: lglaeser@siu.edu; Tel.: +1-503-446-5455

\begin{abstract}
The variation in sodium concentrations in waters of natural fens and marshes on the western Canadian landscape provides a background for choosing the appropriate plants for wetland reclamation. Broad tolerances to salinity are especially important for reclamation trials on saline-rich 'in-pits' that were left from open-pit oil sands mining. One such species, Carex aquatilis, has been identified as a key species in early reclamation attempts; however, at the Sandhill Wetland on the Syncrude Canada oil sands lease, this species has aggressively colonized, dominating parts of the wetland and limiting species diversity. A second species, also widespread on natural lake shores and marshes, is Carex atherodes, with field observations suggesting a broad tolerance to salinity. Here, we examine the responses of this species to a series of sodium concentrations and compare these to those of $C$. aquatilis. In particular, we addressed three questions: (1) How do structural attributes of C. atherodes respond to a series of $\mathrm{Na}^{+}$concentration treatments? (2) Are different structural responses related to the functional attributes of photosynthesis, stomatal conductance, and/or transpiration rate? (3) How do these responses compare to those of C. aquatilis? We implemented a phytotron experiment to test the responses of these two species to either five or six concentrations of sodium, ranging from 20 to $3000 \mathrm{mg} \mathrm{Na}^{+} \mathrm{L}^{-1}$. In general, structural responses of $C$. atherodes did not differ between 50 and $789 \mathrm{mg} \mathrm{Na}^{+} \mathrm{L}^{-1}$, while performances of all attributes were reduced at $1407 \mathrm{mg} \mathrm{L}^{-1}$. Physiological attributes had high variation, but also had reduced performances at similar treatment levels. In comparison, a clear threshold was present for structural attributes in Carex aquatilis between 1650 and $2148 \mathrm{mg} \mathrm{Na}^{+} \mathrm{L}^{-1}$, while physiological attributes were reduced between 1035 to $1650 \mathrm{mg} \mathrm{Na}^{+} \mathrm{L}^{-1}$. These responses from C. aquatilis were similar to those previously reported. $\mathrm{Na}^{+}$concentrations in porewater at the Sandhill Wetland in 2019 reached as high as $1200 \mathrm{mg} \mathrm{Na}^{+} \mathrm{L}^{-1}$, with natural subsaline and sodic sites ranging much higher. Although all of the plants in the treatments remained viable at the end of the experiment, these results indicate that $\mathrm{Na}^{+}$concentrations above $1500-2000 \mathrm{mg} \mathrm{Na}^{+} \mathrm{L}^{-1}$ may inhibit the growth of these two species and decrease their competitive abilities.
\end{abstract}

Keywords: Alberta; boreal; Carex aquatilis; Carex atherodes; oil sands reclamation; Sandhill Wetland; sodium tolerance; wetland

\section{Introduction}

Oil sand deposits lie under $141,000 \mathrm{~km}^{2}$ of the landscape of Alberta, Canada and in 1967, commercial oil sands mining began in northeastern Alberta [1]. Over the past 50 years or so, mining has continued to increase, reaching an oil sands production of $171,084,241 \mathrm{~m}^{3}$ (1.1 billion bbl) in 2019 [2]. One method of oil sands extraction is open-pit mining, which accounts for about $20 \%$ of mining operations and involves the removal of vegetation and surficial deposits in order to access the oil sands deposits containing bitumen [3]. After mining operations are concluded, these large-scale depressions, or in-pits, are refilled with a variety of tailings and process waters that have relatively high concentrations of 
cations and anions [4-6]. Reclamation of in-pit deposits is legislatively mandated to a return to equivalent land capability [7], and these sites include areas of upland and wetland vegetation that provide a new physical landscape [8].

Peatlands (bogs and fens) cover about 27\% of the Oil Sands Administrative Area [9], with nonpeat-forming wetlands (marshes and swamps) being only a minor component [10]. Most abundant on the landscape are rich fens that have pore water chemistries dominated by divalent cations, with $\mathrm{Na}^{+}$concentrations less than $10 \mathrm{mg} \mathrm{L}^{-1}$ and $\mathrm{Ca}^{2+}$ concentrations less than $100 \mathrm{mg} \mathrm{L}^{-1}$ [11]. Brackish and saline marshes are less frequent on the landscape, with these sites having quite different water chemistries $\left(\mathrm{Na}^{+}\right.$ranging from 654 to $2831 \mathrm{mg} \mathrm{L}^{-1}$ and $\mathrm{Ca}^{2+}$ from 35 to $224 \mathrm{mg} \mathrm{L}^{-1}$ ) [12-16]. Currently, there are wetland reclamation projects in the Athabasca Oil Sands Region, but the difficulties and novelty of creating new complex systems that emulate natural systems have hindered concrete protocols and methods $[3,17]$. In early plant establishment, site wetness and chemistry were recognized as the most important limiting factors, and early experimental wetland sites such as Sandhill Wetland were engineered to mitigate these variables [18]. However, the salinity (especially $\mathrm{Na}^{+}$) of oil sands landscapes is considerably higher than what is typical of both bogs and fens $[12,16]$, and depending on its severity, high $\mathrm{Na}^{+}$concentrations can provide a harsh limiting environment for many plants $[19,20]$. Understanding how desired plants will respond to increased $\mathrm{Na}^{+}$concentrations is crucial to successful reclamation.

Purdy et al. [13] described the plant communities of Alberta's boreal landscape along salinity gradients as potential models for oil sands reclamation. Plant species that had an affinity for flooded and wet meadow communities as well as for strongly to slightly saline soils included Carex atherodes, Scolochloa festucacea, Scirpus paludosus, and Triglochin maritima [13]. Furthermore, Carex atherodes was not impacted by the process water of oil sands activity in northwestern Canada after two growing seasons of irrigation in a greenhouse, with up to approximately $569 \mathrm{mg} \mathrm{Na}^{+} \mathrm{L}^{-1}$ [21].

Carex atherodes is circumpolar in distribution, occurring from the arctic and ranging as far south as Arizona and New Mexico in the west, and Missouri and Virginia in the east [22]. It frequently occurs in wet meadows, lake shores, fens, ponds, and marshes [23,24]. Trites and Bayley [16] reported this species from a number of slightly brackish (sites with electrical conductance (EC) between 0.5 and $2.0 \mathrm{mS}$ ) to moderately brackish (sites with EC from 2.0 to $5.0 \mathrm{mS}$ ) marshes in Alberta, including sites with EC from 0.5 to $5.7 \mathrm{mS} \mathrm{cm}^{-1}$. The species did not occur in brackish (sites with EC 5.0-15.0 mS) or subsaline sites (those with EC $15-45.0 \mathrm{mS}$ ) [25]. The natural occurrences of $C$. atherodes in marshes and lake shores [26,27], many with brackish water chemistries [28,29], suggest that this species may provide a key component to the vegetation of sites with moderate to high concentrations of $\mathrm{Na}^{+}$, and for sites where $\mathrm{Na}^{+}$levels exceed those tolerated by other sedges (e.g., C. aquatilis). Just as widespread but occurring commonly in fens is $C$. aquatilis, a species previously examined for habitat limitations [30] and tolerances to $\mathrm{Na}^{+}$[31]. Compared to C. aquatilis, C. atherodes is taller (up to $1.2 \mathrm{~m}$ tall vs. $1.0 \mathrm{~m}$ for C. aquatilis, with more numerous, broader leaves (3-12 mm wide vs. $2.5 \mathrm{~mm}$ for $C$. aquatilis) [24].

Three years after wet-up, Vitt et al. [32] described three plant assemblages as dominant on Sandhill Wetland. The plant assemblage that occurs in areas with both intermediate water levels and salinity continues to be dominated by C. aquatilis, to the extent of excluding many sub-dominant plant species, including ground layer bryophytes. After seven years of plant development, it is apparent that future reclamations should include additional species that are of similar size and aggressiveness to $C$. aquatilis. Based on field observations, Carex atherodes might serve this purpose if it has similar responses to salinity as $C$. aquatilis. The objectives of this study was to further understand the responses to increasing $\mathrm{Na}^{+}$ concentrations of $C$. atherodes. In particular, we addressed these three questions:

1. How do the structural attributes of $C$. atherodes respond to a series of $\mathrm{Na}^{+}$concentration treatments that are present or expected at future in-pit reclamation sites in the Alberta oil sands region? 
2. Are different structural responses related to functional attributes of chlorophyll, photosynthesis, stomatal conductance, and/or transpiration rate?

3. How do these responses compare to those of $C$. aquatilis?

\section{Results}

\subsection{Structural Attributes}

\subsubsection{Biomass}

Aboveground biomass was different among treatments. The highest biomass was produced by $C$. atherodes exposed to $789 \mathrm{mg} \mathrm{Na}^{+} \mathrm{L}^{-1}$ (averaging $4.32 \mathrm{~g}$ ), which decreased dramatically with increasing sodium exposure (Figure 1A). Plants exposed to $789 \mathrm{mg} \mathrm{Na}^{+} \mathrm{L}^{-1}$ produced 1.8 times more aboveground biomass than plants exposed to $1407 \mathrm{mg} \mathrm{Na}^{+} \mathrm{L}^{-1}$ and 5.6 times more aboveground biomass than plants exposed to $2731 \mathrm{mg} \mathrm{Na}^{+} \mathrm{L}^{-1}$.

Belowground biomass production was also different among treatments. The highest biomass was produced by $C$. atherodes exposed to $60 \mathrm{mg} \mathrm{Na}^{+} \mathrm{L}^{-1}$ (averaging $2.59 \mathrm{~g}$ ), then decreased, most dramatically after $789 \mathrm{mg} \mathrm{Na}^{+} \mathrm{L}^{-1}$, with increasing sodium exposure (Figure 1B). Plants exposed to $60 \mathrm{mg} \mathrm{Na}^{+} \mathrm{L}^{-1}$ produced 1.36 times more belowground biomass than plants exposed to $789 \mathrm{mg} \mathrm{Na}^{+} \mathrm{L}^{-1}$; however, the latter produced 2.08 times more below ground biomass than plants exposed to $1407 \mathrm{mg} \mathrm{Na}^{+} \mathrm{L}^{-1}$.

The belowground:aboveground biomass ratio was different among treatments. The lowest treatment, $60 \mathrm{mg} \mathrm{Na}^{+} \mathrm{L}^{-1}$, had the greatest belowground:aboveground ratio, with the 1407 and $2074 \mathrm{mg} \mathrm{Na}^{+} \mathrm{L}^{-1}$ treatments having the lowest ratio. Although all treatments produced a greater amount of aboveground biomass than belowground biomass (Figure 1C).

\subsubsection{Longest Leaf Length}

Among the six treatments, the summed lengths of the longest leaves from the original plant and its ramets varied from $61.1 \mathrm{~cm}$ to $401 \mathrm{~cm}$. Sodium treatments had an effect on the longest leaf length, with a steady decrease in length in the 60 to $2731 \mathrm{mg} \mathrm{Na}^{+} \mathrm{L}^{-1}$ treatments (Figure 1D). Carex atherodes leaves were 2.1 to 6.6 times greater in the treatment with 60 and $789 \mathrm{mg} \mathrm{Na}^{+} \mathrm{L}^{-1}$ than in the $2731 \mathrm{mg} \mathrm{Na}^{+} \mathrm{L}^{-1}$ treatment.

\subsubsection{Ramet Count}

Carex atherodes produced between one and eleven ramets per individual plant. Sodium treatments had an effect on the number of ramets produced, steadily decreasing with increased sodium (Figure 1E). On average, the plants produced about one less ramet for each treatment increase in sodium $\left(60 \mathrm{mg} \mathrm{Na}^{+} \mathrm{L}^{-1}=9\right.$ ramets; $789 \mathrm{mg} \mathrm{Na}^{+} \mathrm{L}^{-1}=7.3$; $1407 \mathrm{mg} \mathrm{Na}^{+} \mathrm{L}^{-1}=7 ; 2074 \mathrm{mg} \mathrm{Na}^{+} \mathrm{L}^{-1}=6 ; 2363 \mathrm{mg} \mathrm{Na}^{+} \mathrm{L}^{-1}=4.2 ; 2731 \mathrm{mg} \mathrm{Na}^{+} \mathrm{L}^{-1}=2.6$ ).

\subsection{Chlorophyll Content}

Chlorophyll content ranged from 17 to 38 and was different among sodium treatments $(\mathrm{df}=5, \mathrm{H}=35.482, p<0.001)$. Plants of $60,789,1407,2074$, and $2363 \mathrm{mg} \mathrm{Na}^{+} \mathrm{L}^{-1}$ treatments were similar; plants of $2731 \mathrm{mg} \mathrm{Na}^{+} \mathrm{L}^{-1}$ were different from those of 60,789 , and $2074 \mathrm{mg}$ $\mathrm{Na}^{+} \mathrm{L}^{-1}$ treatments.

\subsection{Functional Attributes}

\subsubsection{Photosynthetic Rate}

Photosynthetic rate was different among the sodium treatments, decreasing with increased sodium exposure. Carex atherodes exposed to $60 \mathrm{mg} \mathrm{Na}^{+} \mathrm{L}^{-1}$ had photosynthetic rates five times greater than those exposed to $2731 \mathrm{mg} \mathrm{Na}^{+} \mathrm{L}^{-1}$ (Figure 2A). 

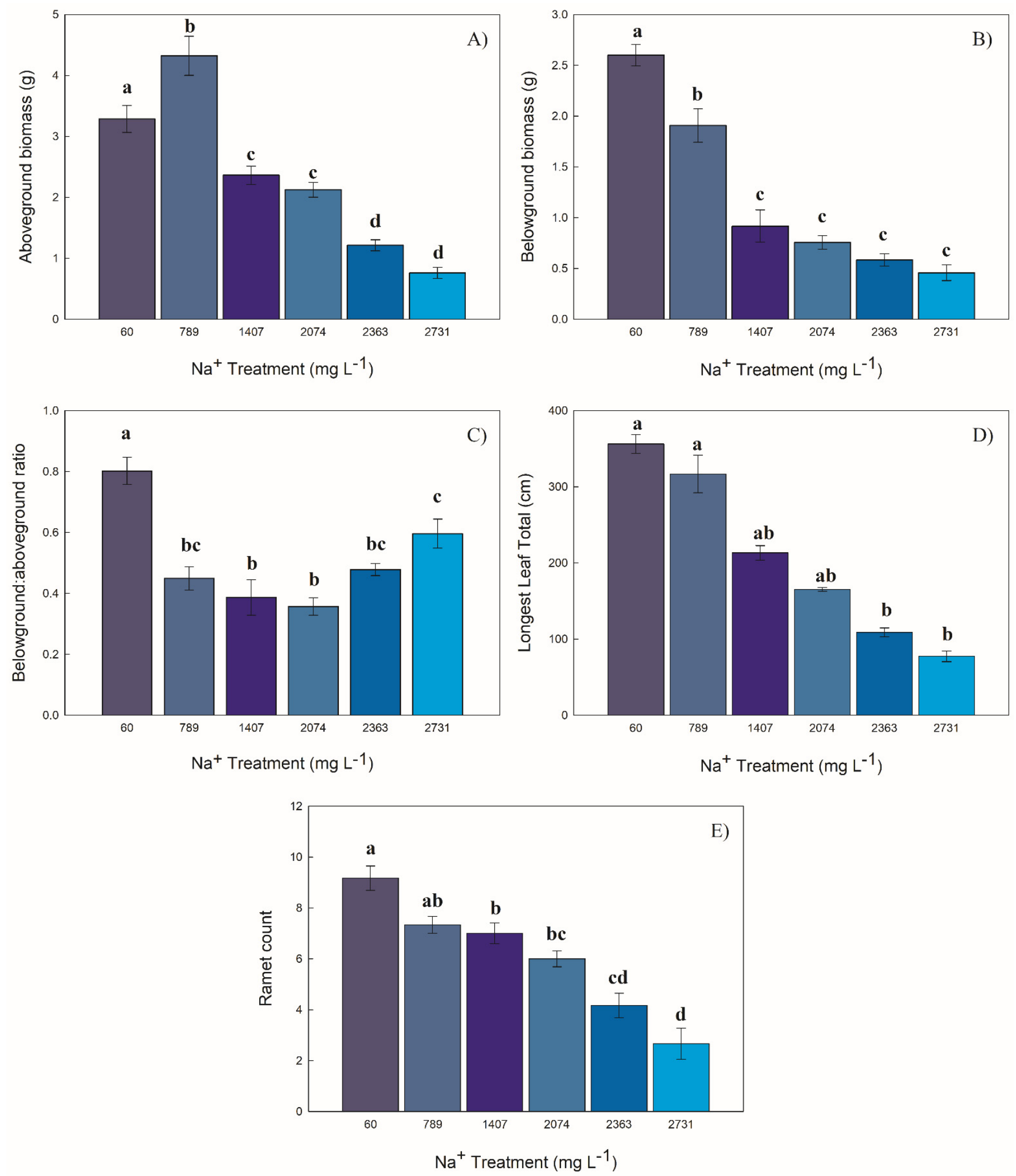

Figure 1. Responses (as mean \pm S.E.) of Carex atherodes to concentrations of sodium. (A) aboveground biomass ( $F=67.54$, $p<0.001)$, (B) belowground biomass $(\mathrm{F}=63.46, p<0.001)$, (C) ratio of belowground biomass to aboveground biomass $(\mathrm{F}=16.81, p<0.001)$, (D) sum of longest leaves $(\mathrm{H}=29.81, p<0.001)$, (E) number of ramets $(\mathrm{F}=27.00, p<0.001)$. Different letters indicate significantly different values between treatments $(\mathrm{F}=$ Tukey's pairwise post hoc test at $p \leq 0.05$ or $\mathrm{H}=\mathrm{Dunn}$ 's pairwise post hoc comparison at $p \leq 0.05$ ). All data from end of experiment. 

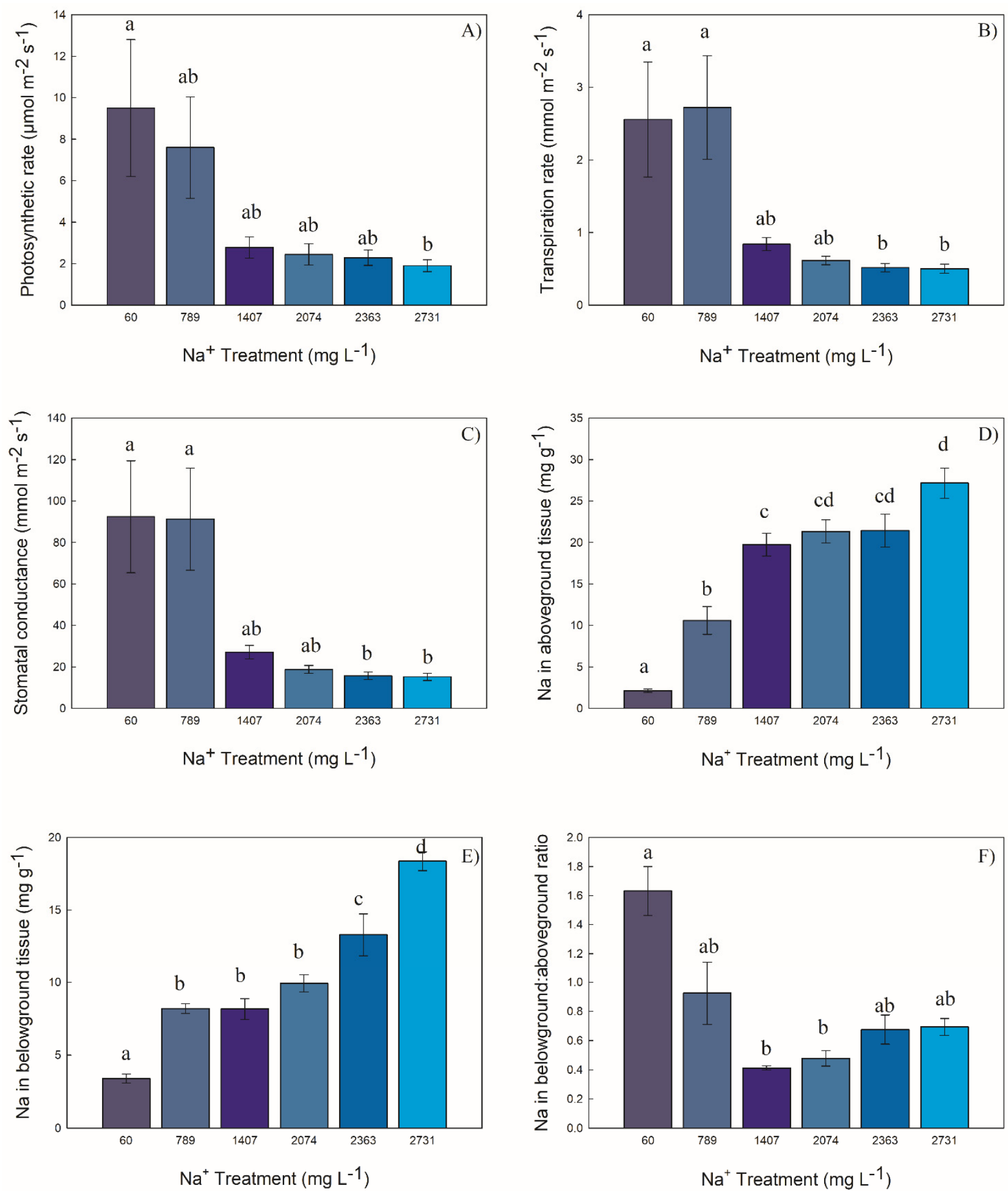

Figure 2. Responses (as mean \pm S.E.) of Carex atherodes to concentrations of sodium. (A) photosynthetic rate $(\mathrm{H}=18.80$, $p=0.002)$, (B) transpiration rate $(\mathrm{H}=30.18, p<0.001)$, (C) stomatal conductance $(\mathrm{H}=31.31, p<0.001$, (D) sodium in aboveground tissue $(\mathrm{F}=35.91, p<0.001)$, (E) sodium in belowground tissue $(\mathrm{F}=54.02, p<0.001)$; $(\mathrm{F})$ ratio of belowground to aboveground tissue concentration of sodium $(\mathrm{H}=21.06, p<0.001)$. Different letters indicate significantly different values between treatments ( $\mathrm{F}=$ Tukey's pairwise post hoc test at $p \leq 0.05$ or $\mathrm{H}=$ Dunn's pairwise post hoc comparison at $p \leq 0.05)$. All data from end of experiment. 


\subsubsection{Transpiration Rate}

Transpiration rate was different among the sodium treatments. The two lowest treatments ( 60 and $789 \mathrm{mg} \mathrm{Na}^{+} \mathrm{L}^{-1}$ ) had plants with rates 4.9 times greater than the two highest treatments (2363 and $2731 \mathrm{mg} \mathrm{Na}^{+} \mathrm{L}^{-1}$ ) (Figure 2B). Stomatal conductance was correlated with the transpiration rate $\left(p<0.001, \mathbf{R}^{2}=0.99\right)$ and the photosynthesis rate $(p<0.001$, $R^{2}=0.79$ ).

\subsubsection{Stomatal Conductance}

Stomatal conductance was different among the sodium treatments. The two lowest treatments $\left(60\right.$ and $\left.789 \mathrm{mg} \mathrm{Na}^{+} \mathrm{L}^{-1}\right)$ had plants with rates 5.8 times greater than the two highest treatments (2363 and $2731 \mathrm{mg} \mathrm{Na}^{+} \mathrm{L}^{-1}$ ) (Figure 2C).

\subsubsection{Concentration of $\mathrm{Na}$ in Aboveground and Belowground Biomass}

The concentration of $\mathrm{Na}$ in aboveground biomass was different among treatments. Plants exposed to the $789 \mathrm{mg} \mathrm{Na}^{+} \mathrm{L}^{-1}$ sodium treatment had five times the concentration of $\mathrm{Na}$ than the lowest concentration $\left(60 \mathrm{mg} \mathrm{Na}^{+} \mathrm{L}^{-1}\right), 10.6 \mathrm{mg} \mathrm{Na} \mathrm{g}^{-1}$, and $2.1 \mathrm{mg} \mathrm{Na} \mathrm{g}^{-1}$. The greatest concentration was in C. atherodes exposed to $2731 \mathrm{mg} \mathrm{Na}^{+} \mathrm{L}^{-1}$ (averaging $27.16 \mathrm{mg} \mathrm{g}^{-1}$ ) (Figure 2D).

The concentration of $\mathrm{Na}$ in belowground biomass was different among treatments (Figure 2E). The Na concentration increased two-fold from the lowest treatment $(60 \mathrm{mg}$ $\left.\mathrm{Na}^{+} \mathrm{L}^{-1}\right)$ to the next three treatments $\left(789 \mathrm{mg} \mathrm{Na}^{+} \mathrm{L}^{-1}, 1407 \mathrm{mg} \mathrm{Na}^{+} \mathrm{L}^{-1}\right.$, and $2074 \mathrm{mg}$ $\mathrm{Na}^{+} \mathrm{L}^{-1}$ ), three-fold in the $2363 \mathrm{mg} \mathrm{Na}^{+} \mathrm{L}^{-1}$ treatment, and six-fold for the highest treatment (2731 $\mathrm{mg} \mathrm{Na}^{+} \mathrm{L}^{-1}$ ).

The concentration of $\mathrm{Na}$ in the belowground:aboveground biomass ratio was different among treatments. Only the lowest treatment, $60 \mathrm{mg} \mathrm{Na}^{+} \mathrm{L}^{-1}$, had a higher concentration of $\mathrm{Na}$ in the roots than the shoots. The 1407 and $2074 \mathrm{mg} \mathrm{Na}^{+} \mathrm{L}^{-1}$ treatments were about one-fourth the ratio of the lowest treatment (Figure 2F).

\subsubsection{Comparison to Carex aquatilis}

Under control conditions $\left(40 \mathrm{mg} \mathrm{Na}^{+} \mathrm{L}^{-1}\right.$ ), the aboveground biomass of Carex aquatilis averaged $2.1 \mathrm{~g}$, belowground biomass was at $2.3 \mathrm{~g}$, about $36 \%$ and $12 \%$, respectively, lower than those of $C$. atherodes (Table 1). In the $1035 \mathrm{mg} \mathrm{Na}^{+} \mathrm{L}^{-1}$ treatment, C. aquatilis' aboveground biomass decreased by $28 \%$ and its belowground biomass decreased by $43 \%$. Comparatively, in the $789 \mathrm{mg} \mathrm{Na}^{+} \mathrm{L}^{-1}$ treatment, the aboveground biomass of C. atherodes increased by $24 \%$ with a decrease of $27 \%$ for its belowground biomass. Photosynthesis of $C$. aquatilis under control conditions averaged $7.2 \mu \mathrm{mol} \mathrm{m}^{-2} \mathrm{~s}^{-1}$, compared to $9.7 \mu \mathrm{mol} \mathrm{m}^{-2} \mathrm{~s}^{-1}$ for $C$. atherodes; stomatal conductance was $68 \mathrm{mmol} \mathrm{m}^{-2} \mathrm{~s}^{-1}$ for C. aquatilis and $96 \mathrm{mmol} \mathrm{m}^{-2} \mathrm{~s}^{-1}$ for C. atherodes. Photosynthesis and stomatal conductance both decreased dramatically at $1035 \mathrm{mg} \mathrm{Na}^{+} \mathrm{L}^{-1}(37 \%$ and $59 \%$, respectively, with significant differences at $1650 \mathrm{mg} \mathrm{Na}^{+} \mathrm{L}^{-1}$ ). Comparatively, photosynthesis of $C$. atherodes decreased only by $20 \%$ (with no change for stomatal conductance) at $789 \mathrm{mg} \mathrm{Na}^{+} \mathrm{L}^{-1}$. At $1407 \mathrm{mg} \mathrm{Na}^{+} \mathrm{L}^{-1}$, photosynthesis had decreased by $71 \%$ and stomatal conductance by $71 \%$. 
Table 1. Responses for Carex aquatilis to five concentrations of $\mathrm{Na}^{+}$.

\begin{tabular}{|c|c|c|c|c|c|}
\hline Carex aquatilis Results & $40 \mathrm{mg} \mathrm{Na}^{+} \mathrm{L}^{-1}$ & $1035 \mathrm{mg} \mathrm{Na}^{+} \mathrm{L}^{-1}$ & $1650 \mathrm{mg} \mathrm{Na}^{+} \mathrm{L}^{-1}$ & $2148 \mathrm{mg} \mathrm{Na}^{+} \mathrm{L}^{-1}$ & $2792 \mathrm{mg} \mathrm{Na}^{+} \mathrm{L}^{-1}$ \\
\hline Aboveground biomass (g) & $2.07 \pm 0.18 \mathrm{a}$ & $1.49 \pm 0.22 \mathrm{ab}$ & $1.29 \pm 0.13 \mathrm{ab}$ & $0.96 \pm 0.34 \mathrm{~b}$ & $0.78 \pm 0.17 \mathrm{~b}$ \\
\hline Belowground biomass (g) & $2.34 \pm 0.23 \mathrm{a}$ & $1.60 \pm 0.27 \mathrm{ab}$ & $1.35 \pm 0.31 \mathrm{ab}$ & $0.84 \pm 0.39 \mathrm{~b}$ & $0.54 \pm 0.09 \mathrm{~b}$ \\
\hline Longest leaf length (cm) & $265.88 \pm 35.68 \mathrm{a}$ & $145.84 \pm 15.64 \mathrm{ab}$ & $146.38 \pm 8.79 \mathrm{ab}$ & $91.75 \pm 23.84 b$ & $77.83 \pm 11.47 \mathrm{~b}$ \\
\hline Ramet count & $5.66 \pm 1.54 \mathrm{a}$ & $3.25 \pm 0.55 \mathrm{a}$ & $5.67 \pm 0.67 \mathrm{a}$ & $3.17 \pm 0.98 \mathrm{a}$ & $3.17 \pm 0.83 \mathrm{a}$ \\
\hline Below:aboveground biomass & $1.15 \pm 0.08 \mathrm{a}$ & $1.04 \pm 0.12 \mathrm{a}$ & $0.99 \pm 0.16 \mathrm{a}$ & $0.71 \pm 0.18 \mathrm{a}$ & $0.75 \pm 0.11 \mathrm{a}$ \\
\hline $\mathrm{Na}$ in aboveground biomass ( $\mathrm{mg} \mathrm{g}^{-1}$ ) & $1.57 \pm 0.10 \mathrm{a}$ & $6.87 \pm 0.74 \mathrm{a}$ & $9.01 \pm 1.04 \mathrm{ab}$ & $16.66 \pm 2.65 b$ & $15.83 \pm 1.95 b$ \\
\hline $\mathrm{Na}$ in belowground biomass $\left(\mathrm{mg} \mathrm{g}^{-1}\right)$ & $2.46 \pm 0.21 \mathrm{a}$ & $8.13 \pm 0.49 \mathrm{ab}$ & $10.27 \pm 1.22 \mathrm{~b}$ & $13.01 \pm 1.57 \mathrm{~b}$ & $13.50 \pm 1.20 \mathrm{~b}$ \\
\hline $\mathrm{Na}$ in belowground:aboveground ratio & $1.57 \pm 0.14 \mathrm{a}$ & $1.27 \pm 0.10 \mathrm{ab}$ & $1.17 \pm 0.13 \mathrm{ab}$ & $0.91 \pm 0.13 \mathrm{~b}$ & $0.88 \pm 0.16 b$ \\
\hline Chlorophyll content & $34.31 \pm 0.60 \mathrm{a}$ & $32.64 \pm 0.88 \mathrm{a}$ & $31.05 \pm 1.37 \mathrm{ab}$ & $24.66 \pm 1.44 \mathrm{c}$ & $26.31 \pm 1.85 \mathrm{bc}$ \\
\hline Photosynthetic rate $\left(\mu \mathrm{mol} \mathrm{m}{ }^{-2} \mathrm{~s}^{-1}\right)$ & $7.18 \pm 0.82 \mathrm{a}$ & $4.52 \pm 0.36 \mathrm{ab}$ & $3.63 \pm 0.55 b c$ & $4.15 \pm 0.91 \mathrm{ac}$ & $2.35 \pm 0.55 c$ \\
\hline Transpiration rate $\left(\mathrm{mmol} \mathrm{m}^{-2} \mathrm{~s}^{-1}\right)$ & $1.87 \pm 0.19 \mathrm{a}$ & $0.90 \pm 0.05 \mathrm{ab}$ & $0.648 \pm 0.08 \mathrm{bc}$ & $0.46 \pm 0.05 c$ & $0.50 \pm 0.04 c$ \\
\hline Stomatal conductance $\left(\mathrm{mmol} \mathrm{m} \mathrm{m}^{-2} \mathrm{~s}^{-1}\right)$ & $67.85 \pm 7.79 \mathrm{a}$ & $28.14 \pm 1.74 \mathrm{ab}$ & $19.96 \pm 2.65 \mathrm{bc}$ & $15.10 \pm 1.81 \mathrm{c}$ & $15.85 \pm 1.19 \mathrm{c}$ \\
\hline
\end{tabular}

Values are means \pm S.E. Different letters indicate significantly different values between treatments from either Tukey's pairwise post hoc test at $p \leq 0.05$ or $\mathrm{H}=$ Dunn's pairwise post hoc comparison at $p \leq 0.05$ ). All data from end of experiment.

\section{Discussion}

\subsection{Variation in Sodium at Natural Sites and at Sandhill Wetland}

The natural rich fens of boreal Alberta are dominated by a small suite of Carex species, including C. aquatilis, C. chordorrhiza, C. diandra, C. lasiocarpa, and/or C. limosa [12,33-35]. Associated with these species is porewater chemistry that is relatively high in divalent cations $\left(\mathrm{Ca}^{2+}, \mathrm{Mg}^{2+}\right)$ and low in $\mathrm{Na}^{+}$. Considerable variation in electrical conductance (EC) results from variation in divalent cations, with $\mathrm{Na}^{+}$providing only a small fraction of charge influencing EC (Figure 3A). In comparison, shallow marshes (both fresh and brackish), lake shores, open riparian zones, and meadows have a flora composed of Carex aquatilis, $C$ atherodes, C. rostrata (s.l.), the grass Calamagrostis canadensis, and/or Typha latifolia [36]. The porewater chemistry of these site types is comparatively higher in $\mathrm{Na}^{+}$, leading to brackish and eventually to saline and sodic wetlands. Sodium concentrations along the brackish-saline-sodic gradient are strongly associated with EC and can attain high values (Figure 3). Porewater chemistry at Sandhill Wetland has sodium concentrations that have increased steadily over the first seven years since wet-up, with the highest concentrations of $\mathrm{Na}^{+}$recorded in 2019 at $1646 \mathrm{mg} \mathrm{L}^{-1}$ and an overall site mean of $496 \mathrm{mg} \mathrm{L}^{-1}$ [37]. These concentrations of sodium far exceed those present in natural fens of the region (Figure 3). The selection of foundation species that respond to brackish/saline water chemistries is a key component in the reclamation of in-pit deposits.

\subsection{Carex atherodes-Responses of Structural and Functional Attributes}

Carex atherodes responded with decreased performance in most structural attributes above a treatment of $789 \mathrm{mg} \mathrm{Na}^{+} \mathrm{L}^{-1}$, with significant differences manifested at a treatment of $1407 \mathrm{mg} \mathrm{Na}^{+} \mathrm{L}^{-1}$. Structural attributes deceased between 35 and $75 \%$ at $1407 \mathrm{mg} \mathrm{Na}^{+} \mathrm{L}^{-1}$. In comparison, functional attributes were different only at higher treatments, almost certainly due to high variation in the 60 and $789 \mathrm{mg} \mathrm{Na}^{+} \mathrm{L}^{-1}$ treatments and the lack of variation in the higher treatments. Functional attributes above $1407 \mathrm{mg} \mathrm{Na}^{+} \mathrm{L}^{-1}$ were remarkably stable with consistently low responses. Photosynthetic rates were strongly associated with the transpiration rate and stomatal conductance, and all of these attributes decreased over four times at a treatment of $1407 \mathrm{mg} \mathrm{Na}^{+} \mathrm{L}^{-1}$; however, significant decreases were not present until a treatment of 2383 or $2731 \mathrm{mg} \mathrm{Na}^{+} \mathrm{L}^{-1}$. Sodium in belowground tissues were similar until a treatment level of $2383 \mathrm{mg} \mathrm{Na}^{+} \mathrm{L}^{-1}$, but above ground tissue concentrations increased steadily over the six treatments. Sodium concentrations in both belowground and aboveground tissues steadily increased as treatment levels rose, with a strong decrease in below-to-aboveground ratios at a treatment of $1407 \mathrm{mg} \mathrm{Na}^{+} \mathrm{L}^{-1}$, suggesting the saturation of the belowground biomass that resulted in higher aboveground Na tissue concentrations. 


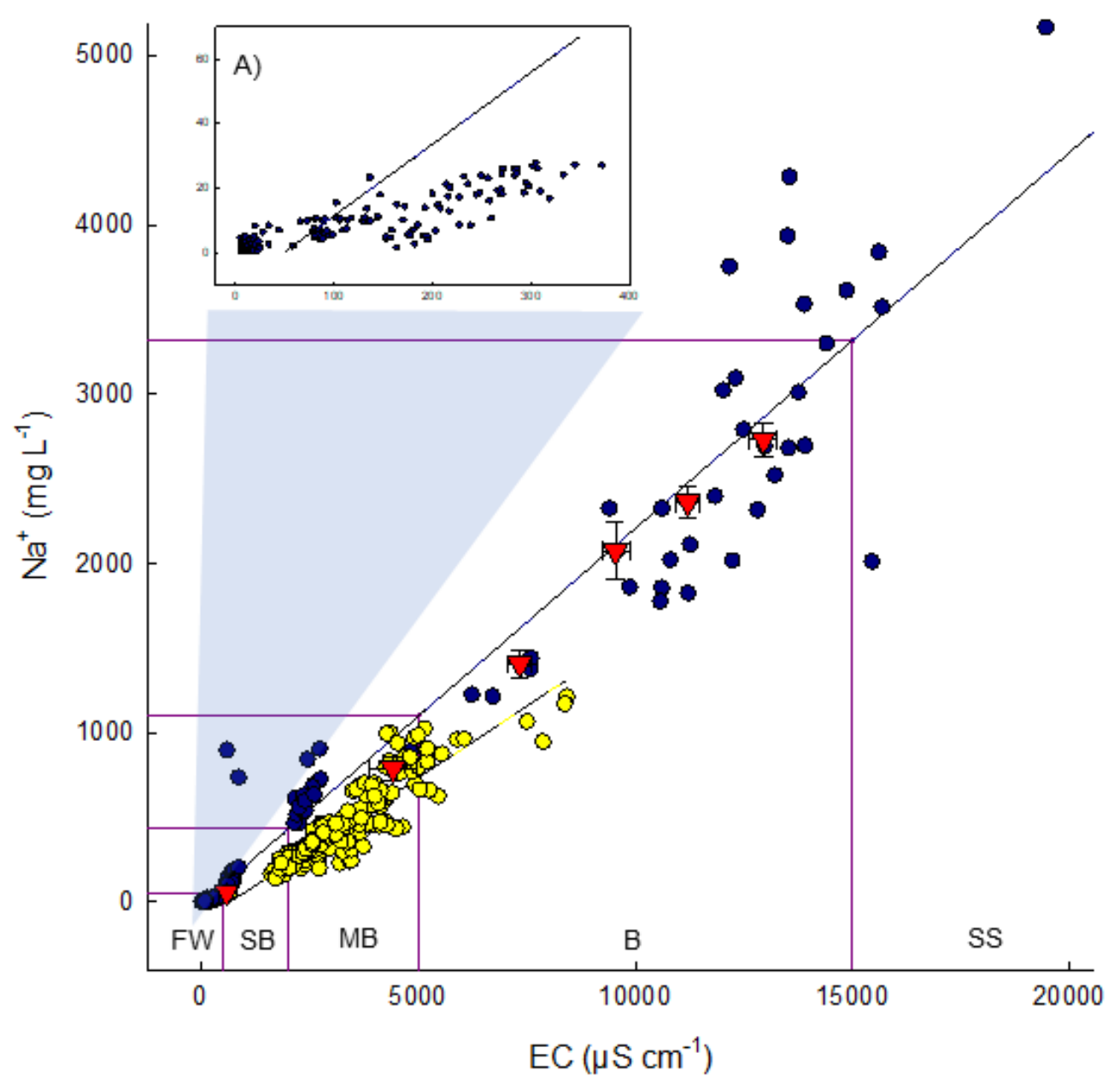

Figure 3. Relationship of $\mathrm{Na}^{+}$to electrical conductance for surface water samples taken from natural subsaline and saline wetlands (blue), samples from Sandhill Wetland (yellow), mean \pm S.E. values of concentrations from the six $\mathrm{Na}^{+}$treatments in this study (red triangles). Boxes are wetland classifications: FW-Freshwater $(\mathrm{EC}<500)$, SB-Slightly brackish $(E C=500-2000)$, MB-Moderately brackish $(E C=2000-5000)$, B-Brackish $(E C=5000-15,000)$, SS-Subsaline $(E C=15,000-45,000)$ [25]. Regression: $\mathrm{Na}^{+}=0.22 * E C-10.73$. (A) Inset shows surface water samples from natural fens expanded. Data from natural sites taken from 2017 to 2018 from [12], and from Sandhill Wetland from 2019 [36].

\subsection{Comparison to Carex Aquatilis}

Carex atherodes produced about $34 \%$ more overall biomass than C. aquatilis under control conditions; likewise, the photosynthesis rate was 37\% higher for C. atherodes. Under field conditions, $C$. atherodes is a much more robust plant, both in terms of height and leaf width. At the lowest treatment level $\left(789 \mathrm{mg} \mathrm{Na}^{+} \mathrm{L}^{-1}\right)$, C. atherodes increased aboveground biomass and decreased belowground biomass, suggesting some tolerance of aboveground tissue to increased $\mathrm{Na}^{+}$concentrations. Comparatively, at a slightly higher treatment $\left(1035 \mathrm{mg} \mathrm{Na}^{+} \mathrm{L}^{-1}\right)$, the biomass of $C$. aquatilis decreased by $30 \%$, with significant differences in responses only present above the $2148 \mathrm{mg} \mathrm{Na}^{+} \mathrm{L}^{-1}$ treatment. Chlorophyll contents (measured using a SPAD meter) of the two species were similar (in the range of 17-38 for C. atherodes and 26-34 for C. aquatilis), both exhibiting reduced numbers above ca. $2000 \mathrm{mg} \mathrm{Na}^{+} \mathrm{L}^{-1}$. All three functional responses produced a reduced performance above the $1035 \mathrm{mg} \mathrm{Na}^{+} \mathrm{L}^{-1}$ treatment. Although our objectives did not include an examination of the mechanisms of salt tolerance, the concentrations of $\mathrm{Na}$ in both the aboveground and belowground tissues of $C$. atherodes suggest a different mechanism from that of $C$. aquatilis. In this mechanism, there is some evidence of salt being concentrated in the root tissue until very high concentrations, where root biomass is much reduced. Previous experiments concluded that $C$. aquatilis had reduced performance above a treatment of $1079 \mathrm{mg} \mathrm{Na}^{+} \mathrm{L}^{-1}$, 
which manifested in a treatment of $2354 \mathrm{mg} \mathrm{Na}^{+} \mathrm{L}^{-1}$, with significant differences in the same structural and functional characteristics [38]. Similar to C. aquatilis [38], the transpiration rates of $C$. atherodes are highly correlated with stomatal conductance, indicating a similar relationship to reduced photosynthesis in the two species. The current trials suggest that we can refine the tolerance of $C$. aquatilis to $\mathrm{Na}^{+}$, with reduced performance above a $1650 \mathrm{mg} \mathrm{Na}^{+} \mathrm{L}^{-1}$ treatment and evident at $2148 \mathrm{mg} \mathrm{Na}^{+} \mathrm{L}^{-1}$. Comparatively, C. atherodes showed reduced performance in most attributes above $789 \mathrm{mg} \mathrm{Na}^{+} \mathrm{L}^{-1}$, with significant differences manifested at a treatment of $1407 \mathrm{mg} \mathrm{Na}^{+} \mathrm{L}^{-1}$. In similar trials, Koropchak and Vitt [39] found decreased survivorship and biomass of T. latifolia at $600 \mathrm{mg} \mathrm{Na}^{+} \mathrm{L}^{-1}$, while Glaeser et al. [40] found decreased performances and biomass of Beckmannia syzigachne after $850 \mathrm{mg} \mathrm{Na}^{+} \mathrm{L}^{-1}$. The higher tolerances of both species of Carex indicate that these two species may provide the key ingredients to the vegetative recovery of oil sands sites with brackish waters.

\section{Materials and Methods}

We used water chemistry collected at Sandhill Wetland in 2019 to explore in-pit reclamation conditions seven years post-wet-up. The 58 ha Sandhill Watershed is an experimental site on a formerly mined-out in-pit located on Syncrude Canada Ltd. oil sands lease at $57.040^{\circ} \mathrm{N}, 111.596^{\circ} \mathrm{W}$ at $310 \mathrm{~m}$ elevation [18]. Its construction consisted of backfilling the 60-100 $\mathrm{m}$ deep in-pit with composite and pure sand tailings between 1999 and 2008. Ten meters of sand were mechanically placed, which shaped the present-day watershed. The 17 ha central wetland was completed by placing half a meter of clay soil designed to reduce hydraulic conductivity and covered by $0.5-1.0$ of salvaged peat obtained from a peatland with both fen and bog site types. The wetland was seeded in winter 2011 with a mix composed largely of Carex aquatilis [31]; however, other Carex species, including C. atherodes, have been growing at the study site (first recorded in 2015). Water from a nearby lake was introduced to the study area in late summer 2012. Currently, the wetland has a nearly complete cover of graminoid vegetation. In 2013, mean $\mathrm{Na}^{+}$concentrations across the entire wetland were at $84.2 \pm 7.2 \mathrm{mg} \mathrm{L}^{-1}$. Sodium concentrations increased in 2016 to $389 \pm 21.7 \mathrm{mg} \mathrm{L}^{-1}$, and in 2019 to $494.2 \pm 9.7 \mathrm{mg} \mathrm{L}^{-1}$. In 2019, sites on the wetland had $\mathrm{Na}^{+}$concentrations as high as $1646.1 \mathrm{mg} \mathrm{Na}^{+} \mathrm{L}^{-1}$ [36]. In 2017, Carex aquatilis dominated large portions of the wetland, with scattered populations of C. atherodes [32].

\subsection{Experimental Design}

To determine how Carex atherodes responds to increasing levels of sodium, a phytotron experiment was conducted from 24 August 2020 to 11 December 2020 (110 days) using plants grown from seeds collected at Sandhill Wetland (SHW). Carex atherodes was exposed to solutions containing one of six sodium concentrations: $60,789,1407,2074,2363$, and $2731 \mathrm{mg} \mathrm{Na}^{+} \mathrm{L}^{-1}$. We used treatments that contained $\mathrm{Na}^{+}$concentrations naturally occurring in slightly brackish (1), moderately brackish (1), and brackish (4) wetlands (Figure 3). These $\mathrm{Na}^{+}$treatment concentrations are the mean values calculated from the concentrations of $\mathrm{Na}^{+}$utilized in the experiment. The $60 \mathrm{mg} \mathrm{Na}^{+} \mathrm{L}^{-1}$ treatment was used as a control, representing the absolute highest concentration of $\mathrm{Na}^{+}$expected in natural fens of the region [11].

Carex atherodes seeds were collected on 19 September 2019 at SHW. Seeds were wet stratified at $2{ }^{\circ} \mathrm{C}$ on moist paper towels, enclosed in plastic bags for 30 days, and germinated on moist peat at $20^{\circ} \mathrm{C}$ [38]. Germination occurred four months after stratification. Seedlings ( $2-4 \mathrm{~cm}$ high) were transplanted to pots with a mixture of $1 / 3$ perlite $-2 / 3$ vermiculite on 8 July 2020. Each pot was placed in individual polypropylene containers that were filled with a minimum of $400 \mathrm{~mL}$ of distilled water. The water contained Jack's Professional ${ }^{\circledR}$ Water-Soluble Fertilizer (20-3-19 Petunia FeED PlusMg, Allentown, PA; (140.3125 ppm $\mathrm{N})$ ) to ensure that the plants had adequate nutrients. Seedlings grew for 47 days after transplant before exposure to sodium treatments, and after excluding the control treatments, subsequently exposed to $1000 \mathrm{mg} \mathrm{Na}^{+} \mathrm{L}^{-1}$ for one week before treatments. 
Carex aquatilis seeds were treated in the same manner and grown under treatments of $40,1035,1650,2148$, and $2792 \mathrm{mg} \mathrm{Na}^{+} \mathrm{L}^{-1}$ in order to better define the response between 1056 and $2000 \mathrm{mg} \mathrm{Na}^{+} \mathrm{L}^{-1}$ [38].

The experiment was performed in the Southern Illinois University Carbondale $\left(37^{\circ} 42^{\prime} 51.9^{\prime \prime} \mathrm{N} 89^{\circ} 13^{\prime} 21.7^{\prime \prime} \mathrm{W}\right)$ temperature-controlled phytotron facility with ambient sunlight. Thirty-three C. atherodes seedlings were randomly assigned to one of six sodium treatments, each with six replicates (for $C$. atherodes, there were four replicates for the $789 \mathrm{mg} \mathrm{Na}^{+} \mathrm{L}^{-1}$ treatment, while the $1407 \mathrm{mg} \mathrm{Na}^{+} \mathrm{L}^{-1}$ treatment had five replicates). In a similar fashion, 30 seedlings of $C$. aquatilis were randomly assigned to one of five sodium treatments, each with six replicates. Individual plants of both species were randomly rearranged and moved to a different location every two weeks. The $18.4 \mathrm{~cm}$ round polypropylene containers, each containing one plant, were monitored each week using an electrical conductance (EC) meter to ensure plants were not exposed to higher sodium concentrations. If EC was outside its accepted range $(20 \%$ higher or lower than its intended sodium concentration in the stock water), the water was emptied and refilled from stock water. Stock water solutions were prepared for each sodium treatment and contained $7 \mathrm{mg} \mathrm{L}^{-1}$ magnesium, $4 \mathrm{mg} \mathrm{L}^{-1}$ potassium, and $10 \mathrm{mg} \mathrm{L}^{-1}$ calcium to mimic natural fen water conditions [38]. Solutions contained $17 \mathrm{~L}$ of distilled water, magnesium sulfate $\left(\mathrm{MgSO}_{4}\right)$, potassium bicarbonate $\left(\mathrm{KHCO}_{3}\right)$, calcium oxide $(\mathrm{CaO})$, and sodium sulfate $\left(\mathrm{Na}_{2} \mathrm{SO}_{4}\right)$ as well as $1 / 4$ teaspoon of the 20-3-19 fertilizer (140.3125 ppm $\left.\mathrm{N}\right)$. Due to calcium oxide's water-insoluble nature, hydrochloric acid and MES buffer were added to get $\mathrm{CaO}$ into the solution in order to bring the stock solution $\mathrm{pH}$ to a neutral level (average: $7.38 \pm 0.03$ S.E.). Sodium was added as a sulfate as it is the dominant anion at Sandhill Wetland [12].

Water samples from the round polypropylene containers were collected each week and concentrations were analyzed for sodium, magnesium, calcium, and potassium on a Varian 220 FS atomic absorption spectrometer; concentrations were also analyzed for EC-using Orion 4 Star EC meter, and for $\mathrm{pH}$ - using an Accumet AB15 pH meter. The water in the polypropylene containers was replaced each week with the appropriate stock solutions to maintain treatment water chemistry. To avoid an excessive concentration of sodium in the polypropylene containers, distilled water was used for watering between stock water replacements.

For each C. atherodes and C. aquatilis plant and ramets produced within each treatment, the following metrics were quantified at the end of the experiment: (1) longest leaf length (sum of longest single leaf from each shoot), (2) number of ramets, (3) chlorophyll content, (4) stomatal conductance, (5) transpiration rate, (6) photosynthesis rate, and (7) dried aboveground and belowground biomass. To estimate the effects of sodium on the amount of chlorophyll present in photosynthetic tissues, a Minolta SPAD 502 chlorophyll meter (Konica Minolta Sensing, Inc., Osaka) was used to measure relative chlorophyll content (no units) at the beginning and end of the experiment after plants reached a sufficient size (3 mm leaf width for C. atherodes, $1.5 \mathrm{~mm}$ for C. aquatilis). A CI-340 handheld photosynthesis system (CID Bio-Science, Inc., Camas, WA) was used to quantify stomatal conductance, transpiration rate, and photosynthesis rate, with three measurements taken for each plant at the end of the experiment (day 100). After the breakdown of the experiment, plants were rinsed with DI water to remove the soil and dried at $60{ }^{\circ} \mathrm{C}$ for at least $72 \mathrm{~h}$ before measuring aboveground and belowground biomass. Sodium uptake levels in C. atherodes roots and shoots were determined using a standard extraction protocol [41].

\subsection{Statistical Analyses}

The responses to sodium concentrations were characterized using an analysis of variance performed in SigmaPlot [42]. For analysis, the six $\mathrm{Na}^{+}$treatment concentrations for C. atherodes were $60( \pm 1.23) \mathrm{mg} \mathrm{L}^{-1}, 789( \pm 71.59) \mathrm{mg} \mathrm{L}^{-1}, 1407( \pm 85.66) \mathrm{mg} \mathrm{L}^{-1}, 2074$ $( \pm 171.95) \mathrm{mg} \mathrm{L}^{-1}, 2362( \pm 97.62) \mathrm{mg} \mathrm{L}^{-1}$, and $2731( \pm 102.04) \mathrm{mg} \mathrm{L}^{-1}$. Similarly, the final $\mathrm{Na}^{+}$treatment concentrations for $C$. aquatilis were $40 \mathrm{mg} \mathrm{L}^{-1}, 1035 \mathrm{mg} \mathrm{L}^{-1}, 1650 \mathrm{mg} \mathrm{L}^{-1}$, 
$2148 \mathrm{mg} \mathrm{L}^{-1}$, and $2792 \mathrm{mg} \mathrm{L}^{-1}$. The cationic chemistry of the six treatments closely followed the relationship of $\mathrm{Na}^{+}$to EC found at natural brackish and sodic sites (Figure 3), indicating that our treatment chemistry reflected that of natural $\mathrm{Na}^{+}$-dominated wetlands.

Physiological responses (stomatal conductance, transpiration rate, photosynthesis rate) of the final month, leaf length (longest leaf length of original plant and longest leaf of any ramets at the end of the experiment), aboveground and belowground biomass, and sodium tissue concentrations were examined for sodium-treatment level differences using a one-way analysis of variance (ANOVA) and Tukey's pairwise post hoc comparisons when data passed the Shapiro-Wilks test for normality $(p<0.05$ failure and visual inspection of residuals). If tests for normality and/or equal variance failed, data were square-root transformed or log transformed. If neither transformation improved normality or equal variance, the untransformed data were analyzed using the Kruskal-Wallis one way analysis of variance on ranks, followed by Dunn's pairwise post hoc comparison.

\section{Conclusions}

Natural wetland site types with either fresh or brackish porewaters are often habitats for species of Carex, including $C$. atherodes and C. aquatilis. Both species tolerate porewaters with relatively high concentrations of sodium. Sandhill Wetland currently has many areas with moderately brackish to brackish salinity, including some sites with concentrations up to $1600 \mathrm{mg} \mathrm{L}^{-1}$ of sodium. The structural attributes of C. atherodes demonstrated reduced performance in phytotron trials above $789 \mathrm{mg} \mathrm{Na}^{+} \mathrm{L}^{-1}$ and apparent at $1407 \mathrm{mg} \mathrm{Na}^{+} \mathrm{L}^{-1}$, while $C$. aquatilis had a reduced performance above $1650 \mathrm{mg} \mathrm{Na}^{+} \mathrm{L}^{-1}$ and apparent at $2148 \mathrm{mg} \mathrm{Na}^{+} \mathrm{L}^{-1}$; these results provide evidence that either of these species tolerate levels of sodium presently recorded at Sandhill Wetland. Although functional attributes for both species become significant at somewhat higher treatments, the large decrease in performance in photosynthesis, transpiration rate, and stomatal conductance in treatments parallel to the structural attributes may suggest responses similar to those in structural attributes. These species, with their high tolerances of brackish concentrations of sodium, may be key ingredients for successful in-pit reclamation designs. The presence of additional high concentrations of divalent cations [43] at reclamation sites may enhance the tolerance of these species to high concentrations of sodium; however, this aspect has not been investigated in wetland species.

Author Contributions: Conceptualization, D.H.V. and L.C.G.; methodology, D.H.V., L.C.G. and M.H.; statistical analysis, L.C.G.; writing-original draft preparation, L.C.G. and D.H.V.; writing-review and editing, L.C.G., D.H.V. and M.H.; project administration, D.H.V.; funding acquisition, D.H.V. All authors have read and agreed to the published version of the manuscript.

Funding: This research was funded by Syncrude Canada Ltd. through grant no. 4600101055 to Dale H. Vitt.

Institutional Review Board Statement: Not applicable.

Informed Consent Statement: Not applicable.

Data Availability Statement: Original data are available from the first author upon request and deposited on disc at Southern Illinois University.

Acknowledgments: We thank Syncrude Reclamation and Closure team members (Carla Wytrykush and Jessica Piercey) for logistical assistance and support. We thank field assistants for gathering seeds in Canada. We are grateful to Carla Wytrykush for reading and commenting on a draft of the manuscript.

Conflicts of Interest: The authors declare no conflict of interest. 


\section{References}

1. Indigenous Environmental Network. 2010. Available online: https://www.ienearth.org/what-are-the-tar-sands/ (accessed on 20 July 2021).

2. Government of Alberta. Oil Sands. Reclamation; Government of Alberta: Edmonton, AB, Canada, 2020. Available online: http:/ / oilsands.alberta.ca/FactSheets/FactSheet-Reclamation-2015.pdf (accessed on 21 February 2020).

3. Foote, L. Threshold considerations and wetland reclamation in Alberta's mineable oil sands. Ecol. Soc. 2012, 17, 1-11. [CrossRef]

4. Chalaturnyk, R.J.; Scott, D.J.; Ozum, B. Management of oil sands tailings. Pet. Sci. Technol. 2002, 20, 1025-1046. [CrossRef]

5. Matthews, J.G.; Shaw, W.H.; MacKinnon, M.D.; Cuddy, R.G. Development of composite tailings technology at Syncrude. Int. J. Surf. Min. Reclam. Environ. 2002, 16, 24-39. [CrossRef]

6. MacKinnon, M.D.; Matthews, J.G.; Shaw, W.H.; Cuddy, R.G. Water quality issues associated with composite tailings (CT) technology for managing oil sands tailings. Int. J. Surf. Min. Reclam. Environ. 2001, 15, 235-256. [CrossRef]

7. Harris, M.L. Guideline for Wetland Establishment on Reclaimed Oil Sands Leases, 2nd ed.; Reclamation Working Group, Cumulative Environmental Management Association: Fort McMurray, AB, Canada, 2007; p. 117.

8. Johnson, E.A.; Miyanishi, K. Creating new landscapes and ecosystems: The Alberta oil sands. Ann. N. Y. Acad. Sci. 2008, 1134, 120-145. [CrossRef]

9. Wieder, R.K.; Vile, M.A.; Scott, K.D.; Albright, C.M.; McMillen, K.J.; Vitt, D.H.; Fenn, M.E. Differential effects of high atmospheric $\mathrm{N}$ and S deposition on bog plant/lichen tissue and porewater chemistry across the Athabasca Oil Sands Region. Environ. Sci. Technol. 2016, 50, 12630-12640. [CrossRef] [PubMed]

10. Rooney, R.C.; Bayley, S.E.; Schindler, D.W. Oil sands mining and reclamation cause massive loss of peatland and stored carbon. Proc. Natl. Acad. Sci. USA 2012, 109, 4933-4937. [CrossRef]

11. Vitt, D.H.; Chee, W.L. The relationships of vegetation to surface-water chemistry and peat chemistry in fens of Alberta, Canada. Vegetatio 1990, 89, 87-106. [CrossRef]

12. Hartsock, J.A.; House, M.; Clark, M.G.; Vitt, D.H. A comparison of plant communities and water chemistry at Sandhill Wetland to natural Albertan peatlands and marshes. Ecol. Eng. 2021, 169, 106313. [CrossRef]

13. Purdy, B.G.; MacDonald, S.E.; Lieffers, V.J. Naturally saline boreal communities as models for reclamation of saline oil sand tailings. Restor. Ecol. 2005, 13, 667-677. [CrossRef]

14. Raab, D.; Bayley, S.E. A Carex species-dominated marsh community represents the best short-term target for reclaiming wet meadow habitat following oil sands mining in Alberta, Canada. Ecol. Eng. 2013, 54, 97-106. [CrossRef]

15. Stewart, S.A.; Lemay, T.G. Inorganic Water Chemistry of Saline Fens in Northeastern Alberta (NTS 74D); ERCB/AGS Open File Report 2011-09; Energy Resource Conservation Board, Alberta Geological Survey: Edmonton, AB, Canada, 2011; p. 6.

16. Trites, M.; Bayley, S.E. Vegetation communities in continental boreal wetlands along a salinity gradient: Implications for oil sands mining reclamation. Aquat. Bot. 2009, 91, 27-39. [CrossRef]

17. Vitt, D.; Bhatti, J. Incorporating Ecological Theory into Restoration Planning. In Restoration and Reclamation of Boreal Ecosystems: Attaining Sustainable Development; Vitt, D.H., Bhatti, J., Eds.; Cambridge University Press: Cambridge, UK, 2012 ; pp. 3-12.

18. Wytrykush, C.; Vitt, D.H.; McKenna, G.; Vassov, R. Designing Landscapes to Support Peatland Development on Soft Tailings Deposits. In Restoration and Reclamation of Boreal Ecosystems: Attaining Sustainable Development; Vitt, D.H., Bhatti, J., Eds.; Cambridge University Press: Cambridge, UK, 2012; pp. 161-178.

19. Munns, R.; Tester, M. Mechanisms of salinity tolerance. Annu. Rev. Plant Biol. 2008, 59, 651-681. [CrossRef]

20. Roy, M.C.; Mollard, F.P.O.; Foote, A.L. Do peat amendments to oil sands wet sediments affect Carex aquatilis biomass for reclamation success? J. Environ. Manag. 2014, 139, 154-163. [CrossRef]

21. Pouliot, R.; Rochefort, L.; Graf, M.D. Impacts of oil sands process water on fen plants: Implications for plant selection in required reclamation projects. Environ. Pollut. 2012, 167, 132-137. [CrossRef]

22. Hultén, E. Flora of Alaska and Neighboring Territories; Stanford University Press: Stanford, CA, USA, $1968 ;$ p. 1008.

23. Jeffrey, W.W. Notes on plant occurrence along lower liard river, N.W.T. National Museum of Canada. Bulletin 1961, 171, 32-115.

24. Johnson, D.; Kershaw, L.; MacKinnon, A.; Pojar, J. Plants of the Western Boreal Forest E Aspen Parkland; Lone Pine Publishing and the Canadian Forest Service: Edmonton, AB, Canada, 1995.

25. Alberta Environment and Sustainable Resource Development (ESRD). Alberta Wetland Classification System; Water Policy Branch, Policy and Planning Division: Edmonton, AB, Canada, 2015.

26. Stewart, R.E.; Kantrud, H.A. Vegetation of Prairie Potholes, North Dakota, in Relation to Quality of Water and Other Environmental Factors; Hydrology of Prairie Potholes in North Dakota; U.S. Geological Survey Professional Paper 585D; United States Government Printing Office: Washington, DC, USA, 1972; 35p. [CrossRef]

27. Millar, J.B. Wetland classification in western Canada. In A Guide to Marshes and Shallow Open Water Wetlands in the Grasslands and Parklands of the Prairie Provinces; Report Series Number 37; Canadian Wildlife Service, Environment Canada: Ottawa, ON, Canada, 1976.

28. Walker, B.H.; Coupland, R.T. Herbaceous wetland vegetation in the aspen grove and grassland regions of Saskatchewan. Can. J. Bot. 1970, 48, 696-711. [CrossRef]

29. Zoltai, S.C.; Taylor, S.; Jeglum, J.K.; Mills, G.F.; Johnson, J.D. Wetlands of Boreal Canada. In National Wetlands Working Group, Wetlands of Canada, Ecological Land Classification Series No. 24; Sustainable Development Branch, Environment Canada: Ottawa, ON, Canada; Polyscience Publications, Inc.: Montreal, QC, Canada, 1988; Volume 24, pp. 97-154. 
30. Koropchak, S.; Vitt, D.H.; Bloise, R.; Wieder, R.K. Fundamental Paradigms, Foundation Species Selection, and Early Plant Responses to Peatland Initiation on Mineral Soils. In Restoration and Reclamation of Boreal Ecosystems: Attaining Sustainable Development; Vitt, D.H., Bhatti, J., Eds.; Cambridge University Press: Cambridge, UK, 2012; pp. 76-100.

31. Vitt, D.H.; House, M.; Hartsock, J.A. Final Report for the Ecology of Sandhill Fen 2016-2019; Syncrude Canada, Ltd.: Fort McMurray, $\mathrm{AB}, \mathrm{Canada}, 2020$.

32. Vitt, D.H.; House, M.; Hartsock, J.A. Sandhill Fen, an initial trial for wetland species assembly on in-pit substrates: Lessons after three years. Botany 2016, 94, 1015-1025. [CrossRef]

33. Chee, W.L.; Vitt, D.H. The vegetation, surface-water chemistry and peat chemistry of moderate-rich fens in central Alberta, Canada. Wetlands 1989, 9, 227-261. [CrossRef]

34. Nicholson, B.J. The wetlands of Elk Island National Park: Vegetation classification, water chemistry, and hydrotopographic relationships. Wetlands 1995, 15, 119-133. [CrossRef]

35. Slack, N.G.; Vitt, D.H.; Horton, D.G. Vegetation gradients of minerotrophically rich fens in western Alberta. Can. J. Bot. Rev. Can. Bot. 1980, 58, 330-350. [CrossRef]

36. Nicholson, B.J.; Vitt, D.H. Wetland development at Elk Island National Park, Alberta, Canada. J. Paleolimnol. 1994, 12, 19-34. [CrossRef]

37. House, M.; Vitt, D.H.; Glaeser, L.; Hartsock, J. Changing chemical conditions and water levels at Sandhill Wetland, Alberta, Canada: Effects on plant distributions and abundance. J. Hydrol. Reg. Stud. 2021. under review.

38. Vitt, D.H.; Glaeser, L.C.; House, M.; Kitchen, S.P. Structural and functional responses of Carex aquatilis to increasing sodium concentrations. Wetl. Ecol. Manag. 2020, 28, 753-763. [CrossRef]

39. Koropchak, S.; Vitt, D.H. Survivorship and growth of Typha latifolia L. across a NaCl gradient: A greenhouse study. Int. J. Min. Reclam. Environ. 2013, 27, 143-150. [CrossRef]

40. Glaeser, L.C.; Vitt, D.H.; Ebbs, S. Responses of the wetland grass, Beckmannia syzigachne, to salinity and soil wetness: Consequences for wetland reclamation in the oil sands area of Alberta, Canada. Ecol. Eng. 2016, 86, 24-30. [CrossRef]

41. Iseki, K.; Marubodee, R.; Ehara, H.; Tomooka, N. A rapid quantification method for tissue $\mathrm{Na}^{+}$and $\mathrm{K}^{+}$concentrations in salt-tolerant and susceptible accessions in Vigna vexillata (L.) A. Rich. Plant Prod. Sci. 2017, 20, 144-148. [CrossRef]

42. SigmaPlot; Version 11; Systat Software, Inc.: San Jose, CA, USA, 2008.

43. Subbarao, G.V.; Johansen, C.; Jana, M.K.; Rao, J.K. Effects of the sodium/calcium ratio in modifying salinity response of pigeonpea (Cajanus cajan). J. Plant Physiol. 1990, 136, 439-443. [CrossRef] 